\title{
COMPARED EFFICACY OF INTRA-ARTICULAR INJECTION OF METHYLPREDNISOLONE AND TRIAMCINOLONE
}

\section{COMPARAÇÃO DE EFICÁCIA DE INJEÇÃO INTRA-ARTICULAR DE METILPREDNISOLONA E TRIANCINOLONA}

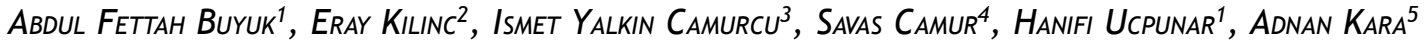 \\ 1. Baltalimani Bone Diseases Research and Training Hospital, Istanbul, Turkey. \\ 2. Golhisar State Hospital, Burdur, Turkey. \\ 3. Medical Faculty, Erzincan University, Erzincan, Turkey. \\ 4. Umraniye Training and Research Hospital, Istanbul, Turkey. \\ 5. Medical Faculty, Istanbul Medipol University, Istanbul, Turkey.
}

\section{ABSTRACT}

Objective: To compare the effect of two different corticosteroid types in bilateral and symmetrical knee osteoarthritis $(\mathrm{OA})$. Methods: One hundred and twenty-six patients received injections of methylprednisolone acetate (MP) in one knee and triamcinolone hexacetonide $(\mathrm{TH})$ in the contralateral knee. Patients were evaluated before injection and 2, 4, 8, 12, and 24 weeks after. Results: Mean patient age was $68.5 \pm 9$ years. Mean BMI was $26.3 \pm 2.6 \mathrm{~kg} / \mathrm{m}^{2}$. At first admission, mean VAS score was $7.7 \pm 1.3$ for the right side and $7.5 \pm 1.5$ for the left side, and mean WOMAC score was 67.6 \pm 14.4 . After bilateral intra-articular injection, VAS scores for both knees and WOMAC scores decreased significantly when initial scores were compared with 2, 4, 8, 12, and 24 weeks after injection $(p<0.05)$. A statistically significant change was seen over time when VAS and WOMAC scores for 2, 4, 8, 12, and 24 weeks post-injection were compared to each other $(p<0.05)$. No significant difference was seen between knee sides $(p>0.05)$. Conclusion: MP and TH have similar efficacy in relieving pain and improving function. The efficacy of intra-articular corticosteroid injection peaks 2 weeks after injection and the effect continues until the $24^{\text {th }}$ week. Level of Evidence II, Comparative Prospective Study.

Keywords: Osteoarthritis, knee. Injections, intra-articular. Methylprednisolone/administration \& dosage. Triamcinolone. acetonide/ administration \& dosage.

\section{RESUMO}

Objetivo: Comparar o efeito de dois tipos de corticosteroides em osteoartrite (OA) de joelho bilateral e simétrica. Métodos: Cento e vinte e seis pacientes receberam injeções de acetato de metilprednisolona (MP) em um joelho e de triancinolona hexacetonida (TH) no joelho contralateral. Os pacientes foram avaliados antes da injeção e 2, 4, 8, 12 e 24 semanas depois. Resultados: A média de idade dos pacientes foi $68,5 \pm 9$ anos. O IMC médio foi $26,3 \pm 2,6 \mathrm{~kg} / \mathrm{m}^{2}$. Na primeira internação, o escore médio da EVA foi 7,7 $\pm 1,3$ para o lado direito e 7,5 $\pm 1,5$ para o esquerdo e a média do escore WOMAC foi $67,6 \pm 14,4$. Depois da aplicação bilateral das injeções intra-articular, os escores da EVA e do WOMAC para ambos os joelhos diminuíram significantemente ao comparar os escores iniciais com os de 2, 4, 8, 12 e 24 semanas depois da injeção $(p<0,05)$. Constatou-se diferença estatisticamente significante no decorrer do tempo, quando os escores EVA e WOMAC às 2, 4, 8, 12 e 24 semanas depois da injeção foram comparados entre si $(p<0,05)$. Não houve diferença significante entre os lados direito e esquerdo $(p>0,05)$. Conclusão: MP e TH têm eficácia similar quanto ao alívio da dor eà melhora da função. A eficácia da injeção intra-articular de corticosteroides atinge o máximo duas semanas depois da aplicação e o efeito continua até a 24a semana. Nível de Evidência II, Estudo Prospectivo Comparativo.

Descritores: Osteoartrite do joelho. Injeções intra-articulares. Metilprednisolona/administração \& dosagem. Triancinolona acetonidal administração \& dosagem.

Citation: Buyuk AF, Kilinc E, Camurcu IY, Camur S, Ucpunar H, Kara A. Compared efficacy of intra-articular injection of methylprednisolone and triamcinolone. Acta Ortop Bras. [online]. 2017;25(5):206-8. Available from URL: http://www.scielo.br/aob.

\section{INTRODUCTION}

Osteoarthritis of the knee is a major cause of pain and disability in older adults. ${ }^{1}$ Pain control is one of the main goals in treating knee $\mathrm{OA} .{ }^{2}$ Management of this disease begins with conservative treatment such as physical therapy, exercise, weight loss, and medications; surgical intervention can be indicated for patients with advanced OA. ${ }^{3}$ Intra-articular corticosteroid injections (IACI) are frequently used and recommended by the American College of Rheumatology as part of conservative therapy for knee OA. ${ }^{4}$ The clinical benefits of $\mathrm{IACl}$ have been evaluated in several studies. ${ }^{5-7}$ Some studies have raised concerns about progression of cartilage destruction, but others have shown that corticosteroid injections can reduce this progression. ${ }^{8,9}$ The literature describes various inconsistent results from IACl; although some studies suggest short-term benefits (usually for one

All authors declare no potential conflict of interest related to this article.

This work was performed at Baltalimanı Bone Diseases Research and Training Hospital and Golhisar State Hospital.

Correspondence: Eray Kilinc. Orthopedic Surgeon at Golhisar State Hospital, Burdur, Turkey. dreraykilinc@gmail.com

Article received in 11/25/2016, approved in 12/19/2016. 
to four weeks), others suggest benefits may last up to 24 weeks. ${ }^{10,11}$ Some studies also have compared different types of corticosteroids for intra-articular injection. The perceived efficacy and rare adverse effects have made IACl a mainstay of knee OA management. ${ }^{12,13}$ Methylprednisolone acetate and triamcinolone hexacetonide are the most commonly used intra-articular corticosteroids. ${ }^{14}$

This present study consists of a randomized, prospective, multicenter investigation to determine the effect of two different types of corticosteroids on OA; this comparison was made by injecting bilateral and symmetrical knee joints involved with the two most commonly used compounds.

\section{MATERIAL AND METHODS}

After written consent was obtained from all patients and approval by the institutional review board (process number 10840098604.01,01-E.3351, 1/3/2016), 126 patients (101 female, 25 male) were included in the study.

All patients presented to the outpatient orthopedic clinic with a bilateral knee pain score of $\geq 4$ points on a 0-10 Visual Analog Scale (VAS) on the day of the examination. Patients were also required to have radiologically verified bilateral grade $3 \mathrm{OA}$ of the knee according to the Kellgren-Lawrence classification. ${ }^{15}$ All patients in this study had dissatisfaction with previous attempts at conservative treatment including non-steroidal anti-inflammatory drugs.

Exclusion criteria were: secondary arthritis, joint instability, IACI within the previous 6 months, history of diabetes mellitus, recent history of trauma to the knee, $\mathrm{BMI}>30$, or presence of cancer or malignant disorders. Patients were also excluded if they had contraindications to injection, such as infection, anticoagulation therapy, allergy or hypersensitivity to any of the study medications. Patients who used systemic corticosteroids were also excluded, as were patients with a difference of $>2$ points between their knees on the VAS.

In this study we did not use a control group. Instead, we compared the medications by injecting methylprednisolone acetate (MP) in one knee and triamcinolone hexacetonide $(\mathrm{TH})$ in the contralateral knee of the same patient. A randomization procedure was followed to assign each compound to the right or the left knee.

Patients were placed in a sitting position with knee flexion of 90 degrees, and a lateral approach to the knee was used. The skin of the injection site was cleaned with povidone-iodine solution. No anesthetic was administered before injection. Either $1 \mathrm{~mL}$ of 40 mg methylprednisolone acetate (Depo-Medrol, Pfizer) mixed with $3 \mathrm{~mL} 1 \%$ lidocaine or $2 \mathrm{~mL}$ of $40 \mathrm{mg}$ triamcinolone hexacetonide (Artropan, Kocak Farma, 20 mg/mL) mixed with $3 \mathrm{~mL} 1 \%$ lidocaine was injected under sterile conditions using a 22G needle. Needles were changed between drawing up the steroid and injection.

Four orthopedic surgeons in three centers applied all of the injections. Additional injections were not permitted during the study period.

A fifth surgeon who was not aware of the study design performed the clinical evaluation. Patients were evaluated before the injection and in control visits 2, 4, 8, 12, and 24 weeks after the injections. Pain severity was evaluated at each visit according to the VAS for each knee, and function was assessed using the WOMAC scale. ${ }^{16}$ Possible complications and side effects were also evaluated at each visit.
The statistical analysis was performed using SPSS 22.0 software (IBM Corp., Chicago, IL, USA). The Kolmogorov-Smirnov test was used to assess normal distribution of the variables. The non-parametric Wilcoxon test was used to compare VAS and WOMAC scores at first admission and at 2, 4, 8, 12, and 24 weeks after injection. The non-parametric Mann-Whitney $U$ test was used to compare VAS scores for the right and left sides at 2, 4, 8, 12, and 24 weeks after injection. Analysis of variance (ANOVA) was used to compare repeated measurements of VAS and WOMAC scores at 2, 4, 8, 12, and 24 weeks after injection.

\section{RESULTS}

The mean age of the 126 patients was $68.5 \pm 9$ years (range: 57-83). Mean patient BMI was $26.3 \pm 2.6 \mathrm{~kg} / \mathrm{m}^{2}$ (range: $21-30$ ). At first admission; mean VAS score was $7.7 \pm 1.3$ for right knees and $7.5 \pm 1.5$ for left knees, and mean WOMAC score was $67.6 \pm$ 14.4. After bilateral intra-articular injection, there was a statistically significant decrease in the initial VAS scores for both knees and WOMAC score in comparison with these measurements taken 2, 4, $8,12$, and 24 weeks after injection $(p<0.05)$. (Table 1$)$ We also found a statistically significant change over time when VAS and WOMAC scores from 2, 4, 8, 12, and 24 weeks after injection were compared to each other $(p<0.05)$, indicating that the pain relieving effect of both agents decreases over time. (Figure 1) No statistically significant difference was seen in VAS scores taken at first admission and 2 , $4,8,12$, and 24 weeks after injection when the right side (injected with methylprednisolone acetate) was compared with the left side (injected with triamcinolone hexacetonide). ( $p>0.05)$ (Table 1)

\section{DISCUSSION}

Knee $\mathrm{OA}$ is a common degenerative joint disease and affects more than one-third of people over age $65 .{ }^{17}$ The most common presenting symptom of $\mathrm{OA}$ is pain. Two meta-analyses concluded that $\mathrm{IACl}$ is clinically and statistically effective in reducing pain. ${ }^{10,18}$ The exact mechanism by which intra-articular corticosteroid injection works is not yet clear, but it is thought that corticosteroids inhibit leukocyte secretion from the synovial cells and decrease synthesis of interleukins and prostaglandins. ${ }^{17}$ Synovial membranes in OA have been shown to be the source of proinflammatory cytokines that may be responsible for the clinical symptoms and progression of OA via cartilage destruction. ${ }^{19}$ A randomized, double-blind placebo controlled study by Raynauld et al ${ }^{20}$ showed that long-term repetitive administration of $\mathrm{IACl}$ is effective for symptom relief and has no destructive effect on the anatomical structures of the knee. Our study demonstrated that both intra-articular triamcinolone and methylprednisolone are effective at reducing pain and improving function in patients with knee $\mathrm{OA}$, and their efficacy may last up to 24 weeks. In this study we observed that for patients who benefited from intra-articular injection, both steroid types had similar effects and duration of efficacy. There are studies comparing corticosteroid types in the literature. Pyne et al. ${ }^{21}$ reported that triamcinolone was statistically more efficient in pain relief 3 weeks after injection than methylprednisolone. In another study, however, Yavuz et al. ${ }^{22}$ stated that methylprednisolone was statistically more effective in relieving pain than other agents including triamcinolone until 6 weeks after injection. In our

Table 1. Mean VAS scores of right and left knee and mean WOMAC scores of the patients.

\begin{tabular}{|c|c|c|c|c|c|c|c|c|}
\hline \multicolumn{3}{|c|}{ First admission ${ }^{\star}$} & \multicolumn{3}{|c|}{ 2nd week ${ }^{*}$} & \multicolumn{3}{|c|}{ 4th week ${ }^{*}$} \\
\hline VAS R & VAS L & WOMAC & VAS R & VAS L & WOMAC & VAS R & VAS L & WOMAC \\
\hline $7.7 \pm 1.3$ & $7.5 \pm 1.5$ & $67.6 \pm 14.4$ & $2.3 \pm 2.2$ & $1.9 \pm 1.8$ & $31.6 \pm 17.3$ & $2.5 \pm 2.4$ & $2.2 \pm 2.1$ & $33.9 \pm 19.1$ \\
\hline \multicolumn{3}{|c|}{ 8th Week* } & \multicolumn{3}{|c|}{ 12th Week* } & \multicolumn{3}{|c|}{ 24th Week* } \\
\hline VAS R & VAS L & WOMAC & VAS R & VAS L & WOMAC & VAS R & VAS L & WOMAC \\
\hline $4.1 \pm 2.7$ & $3.7 \pm 2.6$ & $46.6 \pm 21.8$ & $5.5 \pm 2.2$ & $5.2 \pm 2.4$ & $58.1 \pm 18$ & $5.8 \pm 1.9$ & $5.4 \pm 2.2$ & $61.3 \pm 16.4$ \\
\hline
\end{tabular}



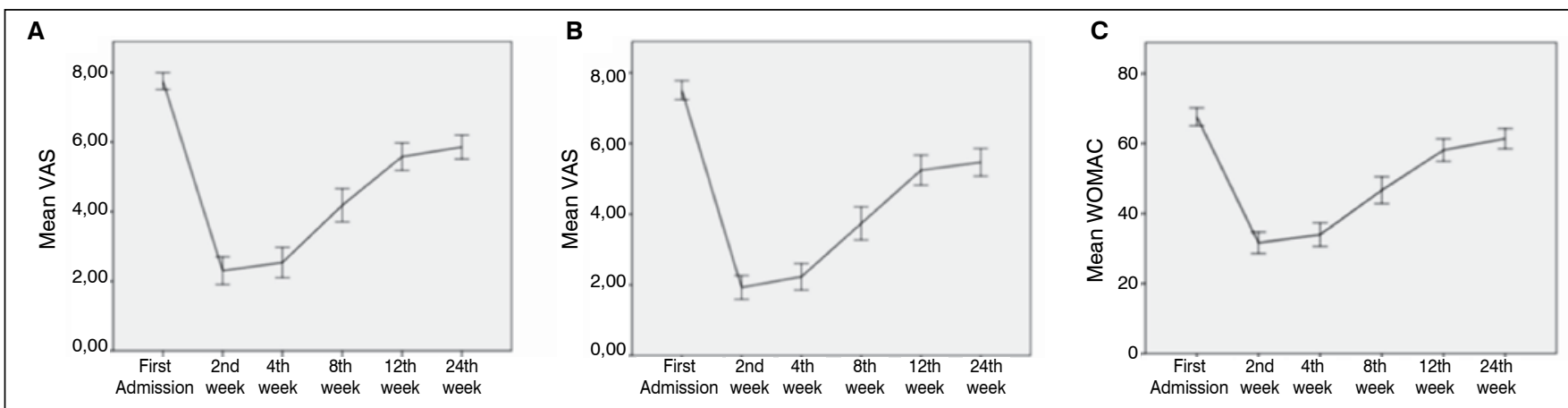

Figure 1. A: Linear graph showing mean VAS scores after injection with methylprednisolone acetate. B: Linear graph of mean VAS scores after injection with triamcinolone hexacetonide. C: Linear graph of mean WOMAC scores for both knees.

own study, no difference was observed between the two types of corticosteroids in terms of pain relief.

Although it is administered locally, a significant portion of the active corticosteroid compound may be absorbed from the joint into the circulation and result in systemic effects. Most of studies in the literature evaluated the hypothalamic-pituitary-adrenal axis. Serum cortisol levels decrease within hours of injection and usually return to recovery level in 1 to 4 weeks, but this may take longer depending on the type and dose of $\mathrm{IACl} .^{23}$ The most common dose preference for the knee joint varies from 20 to $80 \mathrm{mg}$ methylprednisolone or 20 to $40 \mathrm{mg}$ triamcinolone. ${ }^{10,24}$ We used $40 \mathrm{mg}$ triamcinolone and $40 \mathrm{mg}$ methylprednisolone. The most severe complications of $\mathrm{IACl}$ are septic arthritis and steroid-induced arthropathy ${ }_{, 2}^{25}$ but the complications are rare. ${ }^{26}$ In our study, 19 of 126 patients had mild pain at the injection site which subsided in a day; no patients had any significant adverse effects.

This study was limited by the fact that we investigated only two types of corticosteroids. We investigated the most commonly used agents; other types could yield different results. Another limitation is the use of the VAS, an objective test for evaluating outcomes.

\section{CONCLUSION}

In conclusion, bilateral IACl using either methylprednisolone or triamcinolone is safe and effective at reducing pain in patients with bilateral knee OA. Both intra-articular triamcinolone and methylprednisolone have similar efficacy in relieving pain and improving function. The efficacy of IACI is highest 2 weeks after injection and the effect continues to 24 weeks after injection.

AUTHORS' CONTRIBUTIONS: Each author made significant individual contributions to this manuscript. AFB (0000-0003-0316-5444)* and EK (0000-0003$1229-9815)^{\star}$ drafted the manuscript. AFB, EK, and SC (0000-0001-5899-6910* administered the injections, followed patients, and gathered clinical data. IYC $(0000-0002-3900-5162)^{\star}$ and AK (0000-0001-5899-6910)* evaluated the data from the statistical analysis. HU (0000-0001-8394-0708)* AFB, and EK performed the literature search, reviewed the manuscript, and contributed to the intellectual concept of the study. *ORCID (Open Researcher and Contributor ID).

\section{REFERENCES}

1. Hadler NM. Osteoarthritis as a public health problem. Clin Rheum Dis. 1985;11(2):175-85.

2. Raynauld JP, Buckland-Wright C, Ward R, Choquette D, Haraoui B, Martel-Pelletier J, et al. Safety and efficacy of long-term intraarticular steroid injections in osteoarthritis of the knee: a randomized, double-blind, placebo-controlled trial. Arthritis Rheum. 2003;48(2):370-7.

3. Recommendations for the medical management of osteoarthritis of the hip and knee: 2000 update. American College of Rheumatology Subcommittee on Osteoarthritis Guidelines. Arthritis Rheum. 2000;43(9):1905-15.

4. Hochberg MC, Altman RD, April KT, Benkhalti M, Guyatt G, McGowan J, et al. American College of Rheumatology 2012 recommendations for the use of nonpharmacologic and pharmacologic therapies in osteoarthritis of the hand, hip, and knee. Arthritis Care Res (Hoboken). 2012;64(4):465-74.

5. Miller JH, White J, Norton TH. The value of intra-articular injections in osteoarthritis of the knee. J Bone Joint Surg Br. 1958:40(4):636-43.

6. Friedman DM, Moore ME. The efficacy of intraarticular steroids in osteoarthritis: a double-blind study. J Rheumatol. 1980;7(6):850-6.

7. Dieppe PA, Sathapatayavongs B, Jones HE, Bacon PA, Ring EF. Intra-articular steroids in osteoarthritis. Rheumatol Rehabil. 1980;19(4):212-7.

8. Papacrhistou G, Anagnostou S, Katsorhis T. The effect of intraarticular hydrocortisone injection on the articular cartilage of rabbits. Acta Orthop Scand Suppl. 1997;275:132-4.

9. Pelletier JP, Mineau F, Raynauld JP, Woessner JF Jr, Gunja-Smith Z, Martel-Pelletier J. Intraarticular injections with methylprednisolone acetate reduce osteoarthritic lesions in parallel with chondrocyte stromelysin synthesis in experimental osteoarthritis. Arthritis Rheum. 1994;37(3):414-23.

10. Arroll B, Goodyear-Smith F. Corticosteroid injections for osteoarthritis of the knee: meta-analysis. BMJ. 2004;328(7444):869

11. Lomonte $\mathrm{AB}$, de Morais MG, de Carvalho LO, Zerbini CA. Efficacy of Triamcinolone Hexacetonide versus Methylprednisolone Acetate Intraarticular Injections in Knee Osteoarthritis: A Randomized, Double-blinded, 24-week Study. J Rheumatol. 2015;42(9):1677-84.

12. Uthman I, Raynauld JP, Haraoui B. Intra-articular therapy in osteoarthritis. Postgrad Med J. 2003;79(934):449-53.

13. Habib GS, Saliba W, Nashashibi M. Local effects of intra-articular corticosteroids.
Clin Rheumatol. 2010;29(4):347-56

14. Centeno LM, Moore ME. Preferred intraarticular corticosteroids and associated practice: a survey of members of the American College of Rheumatology. Arthritis Care Res. 1994;7(3):151-5.

15. Kellgren JH, Lawrence JS. Radiological assessment of osteo-arthrosis. Ann Rheum Dis. 1957;16(4):494-502.

16. Tüzün EH, Eker L, Aytar A, Daşkapan A, Bayramoğlu M. Acceptability, reliability, validity and responsiveness of the Turkish version of WOMAC osteoarthritis index. Osteoarthritis Cartilage. 2005;13(1):28-33.

17. Ringdahl E, Pandit S. Treatment of knee osteoarthritis. Am Fam Physician. 2011;83(11):1287-92.

18. Godwin M, Dawes M. Intra-articular steroid injections for painful knees. Systematic review with meta-analysis. Can Fam Physician. 2004;50:241-8.

19. Smith MD, Triantafillou S, Parker A, Youssef PP, Coleman M. Synovial membrane inflammation and cytokine production in patients with early osteoarthritis. J Rheumatol. 1997;24(2):365-71.

20. Raynauld JP, Buckland-Wright C, Ward R, Choquette D, Haraoui B, Martel-Pelletier J, et al. Safety and efficacy of long-term intraarticular steroid injections in osteoarthritis of the knee: a randomized, double-blind, placebo-controlled trial. Arthritis Rheum. 2003;48(2):370-7.

21. Pyne D, loannou Y, Mootoo R, Bhanji A. Intra-articular steroids in knee osteoarthritis: a comparative study of triamcinolone hexacetonide and methylprednisolone acetate. Clin Rheumatol. 2004;23(2):116-20.

22. Yavuz U, Sökücü S, Albayrak A, Oztürk K. Efficacy comparisons of the intraarticular steroidal agents in the patients with knee osteoarthritis. Rheumatol Int. 2012;32(11):3391-6.

23. Habib GS. Systemic effects of intra-articular corticosteroids. Clin Rheumatol. 2009;28(7):749-56.

24. Pfenninger JL. Injections of joints and soft tissue: Part II. Guidelines for specific joints. Am Fam Physician. 1991;44(5):1690-701.

25. Neustadt $\mathrm{DH}$. Intra-articular injections for osteoarthritis of the knee. Cleve Clin J Med. 2006;73(10):897-8, 901-4, 906-11.

26. Cheng J, Abdi S. Complications of joint, tendon, and muscle injections. Tech Reg Anesth Pain Manag. 2007;11(3):141-147 